\title{
Relaciones entre las abundancias del bacterioplancton y del fitoplancton en tres ecosistemas lénticos de los Andes Colombianos
}

\author{
Amparo Canosa ${ }^{1} \&$ Gabriel Pinilla ${ }^{2}$ \\ 1 Universidad Jorge Tadeo Lozano. Laboratorio de Microbiología. Carrera 4 No. 22-61. Bogotá, Colombia. Fax: (57) \\ 1-2826197; amparo.canosa@utadeo.edu.co \\ 2 Profesor Asistente, Universidad Nacional de Colombia. Departamento de Biología. Bogotá, Colombia. Fax: (57) 1- \\ 3165310; gapinillaa@unal.edu.co
}

Recibido 27-VIII-2001. Corregido 19-IV-2006. Aceptado 13-X-2006.

\begin{abstract}
Relations between bacterioplankton and phytoplankton abundance in three lentic ecosystems in the Colombian Andes. We analyzed relations among phytoplankton and total bacterioplankton fractions in three lentic ecosystems (Neusa and Prado dams, and Fúquene lagoon) with different physicochemical characteristics, in the Andes of Colombia. Samplings were made in three sites of each water body during three surveys. Neusa dam (meso to oligotrophic) had the lowest bacterial concentration; Prado dam (eutrophic) had a high bacterial and algal abundance, and the Fúquene lagoon (mesotrophic) had lower concentrations of phytoplankton but a high relative concentration of bacteria, probably because of its particular conditions: high organic matter and low nutrient levels in the water. There was a negative correlation of total bacterioplankton with the phytoplankton (Pearson=-0.4479, $\mathrm{p}=0.019, \mathrm{n}=27$ ) and a positive correlation between phytoplankton and heterotrophic bacteria (Pearson $=0.3866, \mathrm{p}=0.062, \mathrm{n}=24)$ and between total bacterioplankton and $\mathrm{DBO}_{5}$ (Pearson=0.4088, $\mathrm{p}=0.034$, $\mathrm{n}=27$ ). Apparently, total bacterioplankton and phytoplankton were not coupling, but cultivable bacteria and the phytoplankton had some degree of relationship. Rev. Biol. Trop. 55 (1): 135-146. Epub 2007 March. 31.
\end{abstract}

Key words: Bacterioplankton, phytoplankton, heterotrophic bacteria, lentic ecosystems, Andean region, Colombia.

En diversos ecosistemas acuáticos se ha encontrado un acoplamiento entre microalgas y bacterias, en el cual la liberación de carbono orgánico disuelto (COD) por parte del fitoplancton controla parcialmente el crecimiento del bacterioplancton; éste a su vez libera nutrientes utilizables por las microalgas, lo que favorece su desarrollo (Currie 1990, Cole et al. 1993, Coveney and Wetzel 1995, del Giorgio et al. 1997, Havens et al. 2000). Dicha relación depende de factores que afectan a las dos comunidades, como temperatura y disponibilidad de fósforo, e influye sobre su productividad, abundancia y composición. Se ha demostrado que la abundancia y producción bacterianas están relacionadas positivamente con la producción primaria del fitoplancton (Cole and Caraco 1993) y que el bacterioplancton utiliza gran parte de las proteínas y aminoácidos provenientes del fitoplancton (Rosenstock and Simon 2001). Sin embargo, estos resultados no son concluyentes; otros autores han encontrado que la respuesta de cada comunidad es independiente, ya que el bacterioplancton está limitado por el fósforo y el fitoplancton por el nitrógeno (Vrede et al. 1999).

En la región neotropical, en la cual parecen existir densidades más constantes de bacterias en el agua que en otras latitudes (Canosa and Pinilla 2001), no se ha evaluado este acoplamiento. En Colombia el fitoplancton se ha usado como indicador biológico y ecológico (Duque and Donato 1992, Roldán 1992, Pinilla 1998, Ramírez 2000), debido a que las microalgas responden a gradientes físicos y 
químicos. Aunque las bacterias se han estudiado con menos frecuencia, cada vez se reconoce más su importancia en los procesos metabólicos de los ecosistemas acuáticos (Canosa and Pinilla 2001, Canosa 2003, Goecke et al. 2004). En el presente trabajo se buscó conocer si existe un posible acople entre las abundancias del fitoplancton y del bacterioplancton en tres ambientes lénticos con diferentes características ubicados en los Andes colombianos. Además, se investigaron las posibles relaciones entre las densidades de dichas comunidades y las características físicas y químicas del agua de los ambientes estudiados.

\section{MATERIALES Y MÉTODOS}

Sitios de muestreo: El embalse de Neusa se ubica a $05^{\circ} 08^{\prime} \mathrm{N}, 75^{\circ} 58^{\prime} \mathrm{W}$, el embalse de Prado a $03^{\circ} 45^{\prime} \mathrm{N}, 74^{\circ} 56^{\prime} \mathrm{W}$ y la laguna de Fúquene a $05^{\circ} 28^{\prime}$ N, 734' W. Todos los cuerpos de agua están situados en la región oriental de la cordillera de los Andes. Neusa es oligo a mesotrófico (Canosa and Pinilla 1999), Prado es eutrófico (Márquez and Guillot 1988) y la laguna de Fúquene es hipereutrófica (Duque 1996) (Fig. 1). La recolección de los datos se realizó en 1997; Neusa se visitó en febrero, abril y mayo y Prado y Fúquene en febrero, abril y junio. Se colectó agua superficial en tres sitios (presa, centro y cola) de cada embalse. En la laguna se muestreó el afluente principal, el centro y el efluente.

Variables fisicoquímicas: Los análisis en campo incluyeron mediciones de oxígeno disuelto, gas carbónico, temperatura, $\mathrm{pH}$, conductividad y sólidos disueltos con equipos portátiles y transparencia con disco Secchi. En el laboratorio se determinaron nutrientes (ortofosfatos, amonio, nitritos, nitratos y nitrógeno total), iones (potasio, sodio, hierro, calcio, sulfatos), alcalinidad, dureza, sólidos suspendidos y demanda biológica de oxígeno $\left(\mathrm{DBO}_{5}\right)$. En todos los casos se siguieron los métodos propuestos por la American Public Health Association (1992).

Poblaciones bacterianas: En cada sitio se tomaron dos muestras directas de agua superficial $(0.5 \mathrm{~m})$ en frascos estériles; una se utilizó inmediatamente en el laboratorio para cuantificar las bacterias heterótrofas por siembra en superficie con agar para recuento (Merck, 5463) según las recomendaciones de APHA (1992); la otra se fijó en campo con gluteraldehído buferado al $2.5 \%$, se mantuvo en oscuridad, refrigerada a $4{ }^{\circ} \mathrm{C}$ y se usó para el conteo total de bacterias con la técnica de epifluorescencia (Kepner and Pratt 1994). Se utilizó como fluorocromo naranja de acridina

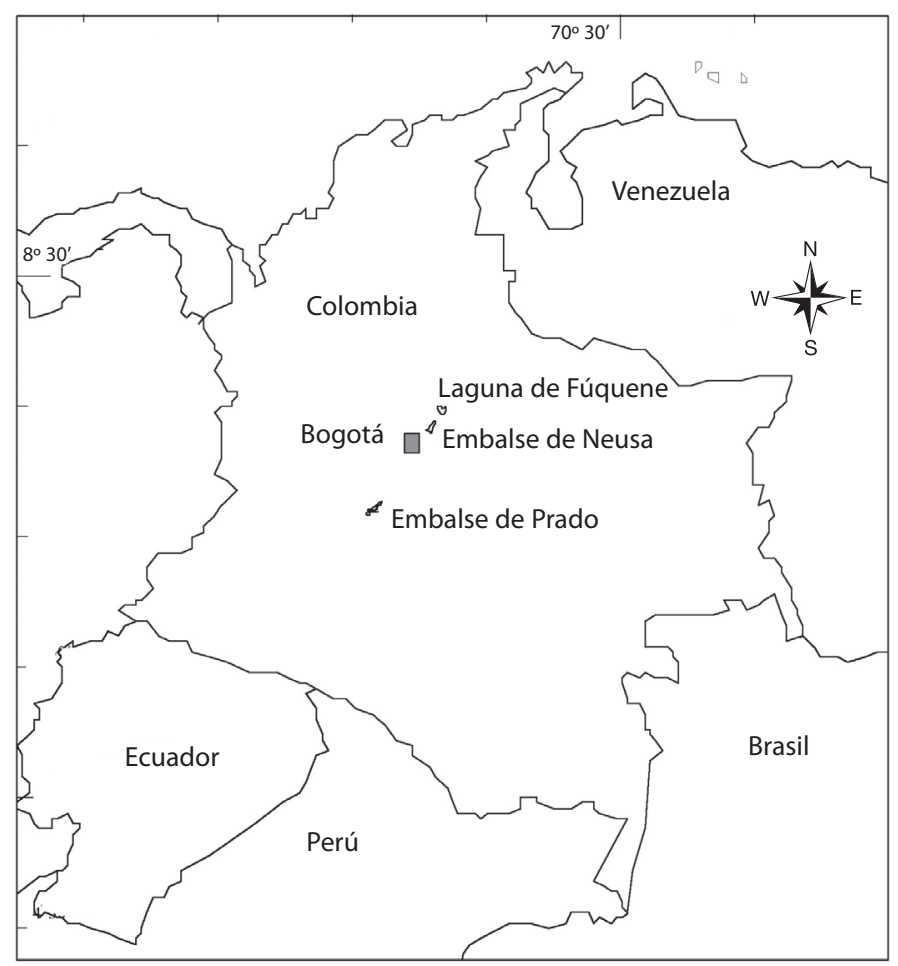

Fig. 1. Localización de los sitios de muestreo en Colombia, Sur América.

Fig. 1. Location of the sampling sites in Colombia, South America. 
en una concentración de $100 \mu \mathrm{g} \mathrm{ml}^{-1} \mathrm{y}$ un tiempo de contacto de cinco minutos, se usaron filtros Nucleopore negros de $0.2 \mu \mathrm{m}$ de diámetro de poro y un microscopio de epifluorescencia Olympus B-Max-60, en cada filtro se contaron al menos 200 células.

Fitoplancton: Las muestras se tomaron a $0.5 \mathrm{~m}$ de profundidad con una botella $\alpha$ horizontal de 2.51 . Se utilizó una submuestra fijada con solución transeau (alcohol-formolagua en proporción 3:1:6) para la identificación de las microalgas; otra se fijó con lugol concentrado y se empleó para la enumeración de las algas (Whitford and Schumacher 1968). La cuantificación se realizó en un microscopio invertido según el método de Lund et al. (1958) en cámaras de sedimentación Utermöhl de $10 \mathrm{ml}$. Para la determinación espectrofotométrica en extracto de acetona de la clorofila $a$ (APHA 1992) se filtraron $500 \mathrm{ml}$ de agua en el ecosistema oligotrófico y $200 \mathrm{ml}$ en los eutróficos.

Análisis estadístico: Para establecer las relaciones entre las variables físicas, químicas y biológicas se utilizó la correlación de Pearson; la comparación entre la abundancia bacteriana total entre los tres ecosistemas se realizó mediante la prueba de Kruskal-Wallis (Blalock 1979). El análisis de clasificación de las especies fitoplanctónicas de todos los cuerpos de agua se hizo con el índice de BrayCurtis mediante la técnica de unión simple (Hammer et al. 2001).

\section{RESULTADOS}

Fisicoquímica del agua: Prado es un embalse profundo, cálido (360 msnm) y eutrófíco con más de $0.03 \mathrm{mg} \mathrm{l}^{-1}$ de ortofosfatos (Cuadro 1). Fúquene es una laguna somera, de aguas frías (2 $500 \mathrm{msnm}$ ), turbias y mineralizadas (conductividad, alcalinidad y dureza altas), con hierro y gas carbónico ligeramente elevados; según Duque (1996) es hipereutrófica, pero nuestros datos señalaron que su condición fluctuó entre oligo y mesotrófica, seguramente por el crecimiento exagerado de
CUADRO 1

Promedios de los parámetros fisicoquímicos en los cuerpos de agua estudiados. Los datos corresponden a tres sitios de cada ecosistema registrados en los tres muestreos realizados

\section{TABLE 1}

Physicochemical parameters means in the water bodies studied. Data belong to three places in each ecosystem registered during the three surveys realized

\begin{tabular}{|c|c|c|c|}
\hline Variable & Neusa & Fúquene & Prado \\
\hline Profundidad promedio (m) & 13.33 & 2.2 & 35.98 \\
\hline Transparencia Secchi (m) & 2.2 & 0.9 & 1.6 \\
\hline Temperatura $\left({ }^{\circ} \mathrm{C}\right)$ & 14.1 & 15.9 & 28.5 \\
\hline $\mathrm{pH}$ & 6.98 & 7.02 & 7.15 \\
\hline $\mathrm{CO}_{2} \mathrm{mg} / 1$ & 5.17 & 10.6 & 5.37 \\
\hline $\mathrm{O}_{2}$ Disuelto $\mathrm{mg} / 1$ & 4.9 & 4.5 & 5.1 \\
\hline Conductividad $\mu \mathrm{S} / \mathrm{cm}$ & 59.4 & 111.6 & 53.2 \\
\hline Sólidos Disueltos mg/l & 34 & 50 & 31 \\
\hline Sólidos Totales mg/l & 642.7 & 55.8 & 45.3 \\
\hline Sólidos Suspendidos mg/l & 3.3 & 5.8 & 20.7 \\
\hline Nitratos mg/l & 0.577 & 0.223 & 0.206 \\
\hline Nitritos mg/l & 0.037 & 0.006 & 0.003 \\
\hline Amonio mg/l & 0.167 & 0.318 & 0.316 \\
\hline Nitrógeno Total mg/l & 8.85 & 5.71 & 7.99 \\
\hline Potasio mg/l & 0.677 & 0.933 & 0.633 \\
\hline Hierro mg/l & 0.265 & 0.833 & 0.09 \\
\hline Calcio mg/l & 4.08 & 7.3 & 5.24 \\
\hline Sodio mg/l & 2.15 & 3.09 & 1.02 \\
\hline Sulfato mg/l & 1.11 & 9.55 & 1.44 \\
\hline Ortofosfatos mg/l & 0.015 & 0.02 & 0.034 \\
\hline $\begin{array}{l}\text { Dureza Ca y } \mathrm{Mg} \\
\mathrm{mgCaCO}_{3} / 1\end{array}$ & 16.02 & 29.89 & 16.52 \\
\hline Alcalinidad & 9.62 & 26.27 & 13.01 \\
\hline Clorofila $a \mathrm{mg} / \mathrm{m}^{3}$ & 8.79 & 4.047 & 10.73 \\
\hline $\mathrm{DBO}_{5} \mathrm{mg} / \mathrm{l}$ & 32.69 & 75.43 & 67.56 \\
\hline
\end{tabular}

macrófitas que acumulan los nutrientes en su biomasa. Neusa es un lago frío (3 $000 \mathrm{msnm}$ ), mesotrófico para los nitratos y oligotrófico para los demás nutrientes. Según la $\mathrm{DBO}_{5}$, Fúquene y Prado, presentaron mayor materia orgánica 
que Neusa. Las aguas superficiales fueron oxigenadas y neutras en todos los cuerpos de agua (Cuadro 1).

Abundancia bacteriana: El conteo bacteriano total promedio fue de $84 \times 10^{4}$ bacterias $\mathrm{ml}^{-1}$ (Cuadro 2), con números que oscilaron entre $19 \times 10^{4}$ y $23 \times 10^{5}$ bacterias $\mathrm{ml}^{-1}$. Las densidades fueron similares en los tres cuerpos de agua, a pesar de que ecológicamente son diferentes. Prado tuvo abundancias algo mayores $\left(93 \times 10^{4}\right.$ bacterias $\left.\mathrm{ml}^{-1}\right)$ y Neusa presentó las menores $\left(75 \times 10^{4}\right.$ bacterias $\left.\mathrm{ml}^{-1}\right)$. Los heterótrofos (conteo en placa) fueron siempre menos abundantes que las poblaciones totales (epifluorescencia). El promedio de heterótrofos en todos los cuerpos de agua fue de $14 \times 10^{2}$ UFC $\mathrm{ml}^{-1}$; Neusa tuvo el mayor número, a pesar de su menor temperatura; en Prado y Fúquene, más contaminados, este grupo presentó valores relativamente bajos (Cuadro 2).
Composición y abundancia fitoplanctónica: En Prado se encontraron 36 especies de fitoplancton; la densidad promedio fue 2077 células $\mathrm{ml}^{-1}$, con predominio de las zigofíceas, las clorofíceas y las cianobacterias (Fig. 2). En Neusa dominaron las diatomeas debido a un florecimiento de Synedra sp. (9 800 células $\mathrm{ml}^{-1}$ ); en este embalse se registraron 63 especies y una densidad promedio de 2917 células $\mathrm{ml}^{-1}$. Fúquene tuvo la mayor cantidad de especies (75) y la menor densidad promedio (291 células $\mathrm{ml}^{-1}$ ); las clorofíceas, euglenofíceas y cianobacterias fueron las mejor representadas. En el cuadro 3 se presenta la lista completa de especies fitoplanctónicas halladas en cada cuerpo de agua. El dendrograma de similaridad con base en la composición de especies (Fig. 3) mostró un agrupamiento claro de cada ecosistema. Solo la laguna de Fúquene y el embalse de Neusa presentan cierto grado de semejanza.

CUADRO 2

Conteo bacteriano total (bacterias $\mathrm{ml}^{-1}$ ) y de heterótrofos (UFC $\mathrm{ml}^{-1}$ ) en cada cuerpo de agua, en los tres muestreos y en cada estación

TABLE 2

Total bacterial (bacteria $\mathrm{ml}^{-1}$ ) and heterotrophs count ( $\mathrm{cfu} \mathrm{ml}^{-1}$ ) in each water bodies at three samplings and at each station

\begin{tabular}{|c|c|c|c|c|c|c|c|}
\hline \multicolumn{2}{|c|}{ Cuerpo de agua } & \multicolumn{2}{|c|}{ Neusa } & \multicolumn{2}{|c|}{ Fúquene } & \multicolumn{2}{|c|}{ Prado } \\
\hline Muestreo & Estación & $\mathrm{C} \mathrm{T}$ & HT & $\mathrm{CT}$ & HT & $\mathrm{CT}$ & HT \\
\hline \multirow[t]{4}{*}{ I } & 1 & $23 \times 10^{5}$ & $33 \times 10^{2}$ & $10 \times 10^{5}$ & - & $13 \times 10^{5}$ & $13 \times 10^{2}$ \\
\hline & 2 & $14 \times 10^{5}$ & 70 & $15 \times 10^{5}$ & - & $10 \times 10^{5}$ & $70 \times 10$ \\
\hline & 3 & $13 \times 10^{5}$ & $23 \times 10$ & $51 \times 10^{4}$ & - & $14 \times 10^{5}$ & $30 \times 10$ \\
\hline & Promedio & $16 \times 10^{5}$ & $12 \times 10^{2}$ & $10 \times 10^{5}$ & - & $12 \times 10^{5}$ & $76 \times 10$ \\
\hline \multirow[t]{4}{*}{ II } & 1 & $17 \times 10^{4}$ & $14 \times 10^{2}$ & $12 \times 10^{5}$ & $16 \times 10^{2}$ & $87 \times 10^{4}$ & $54 \times 10^{2}$ \\
\hline & 2 & $19 \times 10^{4}$ & $85 \times 10$ & $93 \times 10^{4}$ & $20 \times 10$ & $77 \times 10^{4}$ & $10 \times 10^{2}$ \\
\hline & 3 & $19 \times 10^{4}$ & $11 \times 10^{2}$ & $15 \times 10^{5}$ & $95 \times 10$ & $11 \times 10^{5}$ & $75 \times 10$ \\
\hline & Promedio & $18 \times 10^{4}$ & $11 \times 10^{2}$ & $12 \times 10^{5}$ & $92 \times 10$ & $91 \times 10^{4}$ & $23 \times 10^{2}$ \\
\hline \multirow[t]{4}{*}{ III } & 1 & $36 \times 10^{4}$ & $20 \times 10^{2}$ & $36 \times 10^{4}$ & $35 \times 10^{2}$ & $84 \times 10^{4}$ & $15 \times 10^{2}$ \\
\hline & 2 & $26 \times 10^{4}$ & $23 \times 10^{2}$ & $22 \times 10^{4}$ & $35 \times 10$ & $71 \times 10^{4}$ & $85 \times 10$ \\
\hline & 3 & $57 \times 10^{4}$ & $36 \times 10^{2}$ & $26 \times 10^{4}$ & $35 \times 10$ & $38 \times 10^{4}$ & $35 \times 10$ \\
\hline & Promedio & $39 \times 10^{4}$ & $26 \times 10^{2}$ & $28 \times 10^{4}$ & $14 \times 10^{2}$ & $64 \times 10^{4}$ & $90 \times 10$ \\
\hline \multicolumn{2}{|c|}{ Promedio total } & $75 \times 10^{4}$ & $17 \times 10^{2}$ & $83 \times 10^{4}$ & $12 \times 10^{2}$ & $93 \times 10^{4}$ & $14 \times 10^{2}$ \\
\hline
\end{tabular}

CT: Conteo Total HT: Heterótrofos 


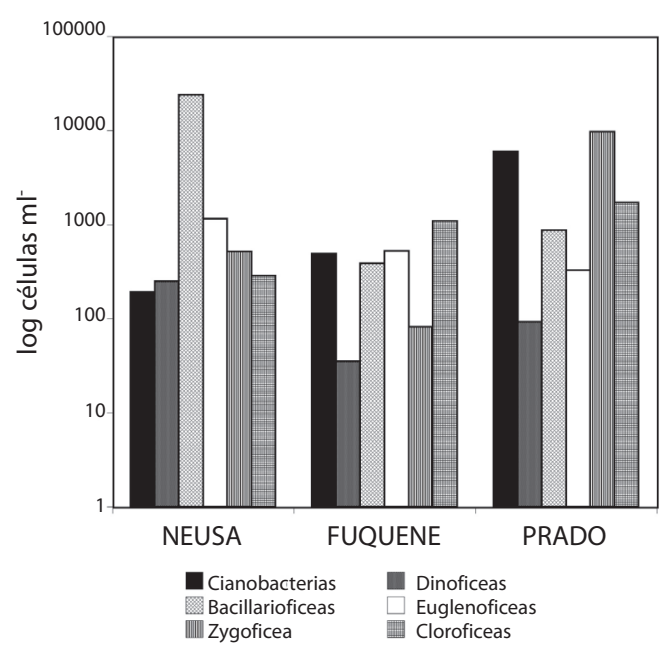

Fig. 2. Abundancias del fitoplancton en los ecosistemas estudiados.

Fig. 2. Phytoplankton abundances in the ecosystems studied.
Concentración de clorofila $a$ : A excepción del primer muestreo, en Neusa la clorofila $a$ (Fig. 4) fue moderadamente alta (7.2 a 11.2 $\mathrm{mg} \mathrm{m}^{-3}$ ); en Fúquene se observaron concentraciones bajas a moderadas (entre 1.3 y $6 \mathrm{mg} \mathrm{m}^{-3}$ )

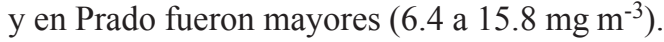
En embalses colombianos de mayor profundidad los rangos de clorofila son relativamente bajos (0.01 a $7.7 \mathrm{mg} \mathrm{m}^{-3}$ (Pino 1995), pero similares a los hallados en Neusa y Prado. En Fúquene Gómez and Pinilla (1996) registraron concentraciones de $18.58 \mathrm{mg} \mathrm{m}^{-3}$, mucho mayores que las encontradas en este estudio, lo que evidenció la disminución del fitoplancton de la laguna con respecto a épocas anteriores.

Relaciones del bacterioplancton con el fitoplancton y con el ambiente fisicoquímico: Al analizar el conjunto de datos de todos los ecosistemas, se encontraron correlaciones significativas entre las abundancias del fitoplancton $\mathrm{y}$ del bacterioplancton total (Pearson= $-0.4479, \mathrm{p}=0.019, \mathrm{n}=27) \mathrm{y}$ entre el bacterioplancton total y la $\mathrm{DBO}_{5}$ (Pearson $=0.4088$, $\mathrm{p}=0.034, \mathrm{n}=27$ ). También se halló una correlación positiva entre el fitoplancton y las bacterias heterótrofas, pero a un nivel de significancia del $90 \%$ (Pearson $=0.3866$, $\mathrm{p}=0.062, \mathrm{n}=24)$. La relación gráfica entre el conteo bacteriano total y la concentración de clorofila $a$ (Fig. 5) indicó una mayor abundancia de bacterias y de clorofila $a$ en el embalse de Prado. Fúquene mostró también abundancias bacterianas altas pero menor concentración de clorofila $a$, debido a una posible limitación del crecimiento algal por ortofosfatos. Prado y Fúquene fueron los sistemas con más materia orgánica. En Neusa hubo mayor concentración de clorofila $a$, pero menos bacterias.

Fig. 3. Cluster analysis of samples in each ecosystem, based in phytoplankto species composition. $\mathrm{P}=$ Prado, $\mathrm{F}=$ Fúquene, $\mathrm{N}=$ Neusa, $\mathrm{M}=$ Sample, $\mathrm{E}=$ Site. 
CUADRO 3

Especies del fitoplancton presentes en la laguna de Fúquene y en los embalses de Neusa y Prado

TABLE 3

Phytoplanktonic species present in Fúquene lagoon and in Neusa and Prado dams

División

Cianobacteria

Cianobacteria

Cianobacteria

Cianobacteria

Cianobacteria

Cianobacteria

Cianobacteria

Cianobacteria

Cianobacteria

Cianobacteria

Cianobacteria

Cianobacteria

Cianobacteria

Cianobacteria

Dinofícea

Dinofícea

Dinofícea

Dinofícea

Dinofícea

Bacillariofícea

Bacillariofícea

Bacillariofícea

Bacillariofícea

Bacillariofícea

Bacillariofícea

Bacillariofícea

Bacillariofícea

Bacillariofícea

Bacillariofícea

Bacillariofícea

Bacillariofícea

Bacillariofícea

Xantofícea

Crisofícea
Especie

Microcystis sp1

Microcystis sp2

Chroococcus $\mathrm{sp} 1$

Dactylococcopsis sp1

Dactylococcopsis sp2

Merismopedia glauca

Spirulina sp1

Oscillatoria af. borneti

Oscillatoria cf. planctonica

Oscillatoria $\mathrm{sp} 2$

Lingbia birgei

Anabaena sphaerica

Anabanenopsis raciborski

Anabaena sp1

Peridinium limbatum

Peridinium cinctum

Peridinium umbonatum

Gimnodinium sp1

Gimnodinium sp2

Synedra sp1

Cimbella $\mathrm{sp} 1$

Cymbella sp2

Gyrosigma sp1

Gomphonema sp1

Surirella linearis

Meridion circulare

Stauroneis sp1

Aulacoseira sp1

Melosira $\mathrm{sp} 1$

Meridion sp1

Tabellaria fenestrata

Tabellaria flocculosa

Istmochloron lobulatum

Dynobrion sp1
Fúquene Neusa

Prado

X

X

X

X

X

X

X

X

X

X

X

X

X

X

X

X

X

X

X

X

X

X

X

X

X

X

$\mathrm{X}$

X

X

$\mathrm{X}$

X

X

X

X

X

X

$X \quad X$

X $\quad X$

$\mathrm{X}$ 
CUADRO 3

Especies del fitoplancton presentes en la laguna de Fúquene y en los embalses de Neusa y Prado

TABLE 3

Phytoplanktonic species present in Fúquene lagoon and in Neusa and Prado dams

División

Euglenofícea

Euglenofícea

Euglenofícea

Euglenofícea

Euglenofícea

Euglenofícea

Euglenofícea

Euglenofícea

Euglenofícea

Euglenofícea

Euglenofícea

Euglenofícea

Euglenofícea

Euglenofícea

Euglenofícea

Euglenofícea

Euglenofícea

Euglenofícea

Euglenofícea

Euglenofícea

Euglenofícea

Euglenofícea

Zigofícea

Zigofícea

Zigofícea

Zigofícea

Zigofícea

Zigofícea

Zigofícea

Zigofícea

Zigofícea

Zigofícea

Zigofícea

Zigofícea
Especie

Euglena acus

Euglena spathirrhyncha

Euglena oxyuris

Euglena cf. variabilis

Phacus longicauda var. longicauda

Phacus cf. prunoideus

Phacus af. minutus

Phacus sp1

Lepocinclis $\mathrm{sp} 1$

Strombomonas urceolata

Trachelomonas volvocina

Trachelomonas sydneyensis var.grandicollis

Trachelomonas armata var. armata

Trachelomonas lemmermannii

Trachelomonas hispidia

Trachelomonas hispidia var. hispidia

Trachelomonas crebea

Trachelomonas af. pulcherrima var latior

Trachelomonas cervicula

Trachelomonas $\mathrm{sp} 1$

Trachelomonas $\mathrm{sp} 2$

Trachelomonas $\mathrm{sp} 4$

Cosmarium af. naegelianum

Cosmarium portianum var. brasiliense

Closterium kuetzingii

Cosmarium $\mathrm{sp} 1$

Cosmarium $\mathrm{sp} 2$

Cosmarium $\mathrm{sp} 3$

Cosmarium sp7

Cosmarium $\mathrm{sp} 8$

Closterium $\mathrm{sp} 1$

Closterium $\mathrm{sp} 2$

Closterium sp3

Closterium sp4

Fúquene Neusa $\quad$ Prado

$X$

X

$X$

X

X

X

X

X

X

X

X

X

X

X

X X

X

X

$\mathrm{X}$

X

X

$\mathrm{X}$

X

X

$\mathrm{X}$

X

$\mathrm{X}$

X

X

X

X 
CUADRO 3

Especies del fitoplancton presentes en la laguna de Fúquene y en los embalses de Neusa y Prado

TABLE 3

Phytoplanktonic species present in Fúquene lagoon and in Neusa and Prado dams

División

Zigofícea

Zigofícea

Zigofícea

Zigofícea

Zigofícea

Zigofícea

Zigofícea

Zigofícea

Zigofícea

Zigofícea

Zigofícea

Zigofícea

Zigofícea

Zigofícea

Zigofícea

Zigofícea

Zigofícea

Zigofícea

Zigofícea

Zigofícea

Zygofíceas

Zigofícea

Clorofícea

Clorofícea

Clorofícea

Clorofícea

Clorofícea

Clorofícea

Clorofícea

Clorofícea

Clorofícea

Clorofícea

Clorofícea

Clorofícea

$$
\text { Especie }
$$

Desmidium cf. cuadrangulare

Pleurotaenium sp1

Staurastrum af. natator

Staurastrum glabrum

Staurastrum leptacantum

Staurastrum leptocladum

Staurastrum chaetoceras

Staurastrum af. gracile

Staurastrum gracile var. nanum

Staurastrum leave

Staurastrum nova-terrae

Staurastrum tetracerum

Staurastrum muticum

Staurastrum glabrum

Staurastrum af. sebaldi

Staurastrum af. natator

Staurastrum sp3

Staurodesmus dejectus var. dejectus

Staurodesmus dejectus var.1

Staurodesmus af. mamilatus

Arthrodemus octocornis

Arthrodesmus divergens

Oedogonium $\mathrm{sp}$

Crucigenia tetrapedia

Crucigenia $\mathrm{sp} 1$

Tetraedron $\mathrm{sp} 1$

Coelastrum reticulatum

Coelastrum microporum

Botryococcus braunii

Sphaerocystis sp1

Pseudosphaerocystis sp1

Planktosphaeria sp1

Oocystis sp1

Nephrocytium agardianum
$\mathrm{X}$

Fúquene Neusa $\quad$ Prado

$\mathrm{X}$

$X$

X

$\mathrm{X}$

X

$X$

X

X

$\mathrm{X}$

$\mathrm{X}$

$\mathrm{X}$

$\mathrm{X}$

$\mathrm{X}$

$\mathrm{X}$

X X

$\mathrm{X}$

X X

$\mathrm{X}$

$\mathrm{X}$

X

$\mathrm{X}$

$\mathrm{X}$

X

X

X

$\mathrm{X}$

$\mathrm{X}$

$X \quad X$

$X \quad X$

$\mathrm{X}$

$X$

$X$

$X$

X
$X$

$X$ 
CUADRO 3

Especies del fitoplancton presentes en la laguna de Fúquene y en los embalses de Neusa y Prado

TABLE 3

Phytoplanktonic species present in Fúquene lagoon and in Neusa and Prado dams

División

Clorofícea

Clorofícea

Clorofícea

Clorofícea

Clorofícea

Clorofícea

Clorofícea

Clorofícea

Clorofícea

Clorofícea

Clorofícea

Clorofícea

Clorofícea

Clorofícea

Clorofícea

Clorofícea
Especie

Nephrocytium limneticum

Nephrocytium lunatum

Kirchneriella sp1

Scenedesmus bijugus

Scenedesmus bijugus af. var.disciformis

Scenedesmus quadricauda var. quadrispina

Scenedesmus acuminatus var. acuminatus

Scenedesmus acuminatus var. minutus

Scenedesmus $\mathrm{sp} 1$

Scenedesmus sp2

Selenastrum $\mathrm{sp} 1$

Ankistrodesmus spirale

Actinastrum gracillium

Pediastrum duplex var. duples

Pediastrum tetras

Pediasturm boryianum
Fúquene

Neusa

X

X

X

X

X

X

X

X

X

X

X

X

X

Prado
X

$\mathrm{X}$

X

X

X

X

X
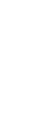

X

X

X

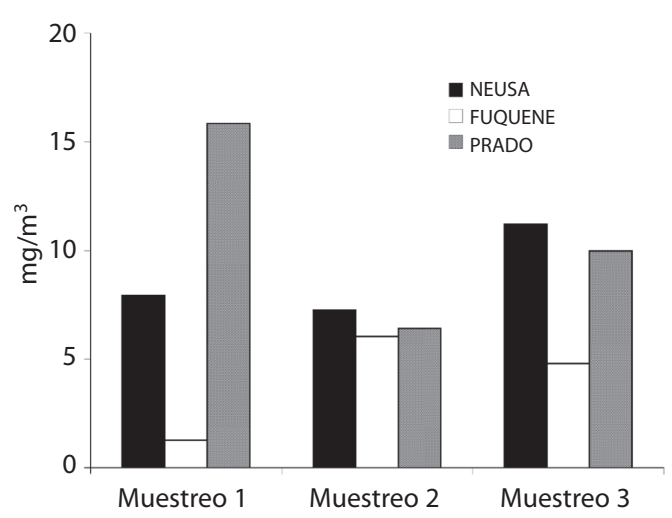

Fig. 4. Concentración promedio de clorofila $a$ en los ecosistemas estudiados.

Fig. 4. Mean chlorophyll $a$ concentration in the ecosystems studied.

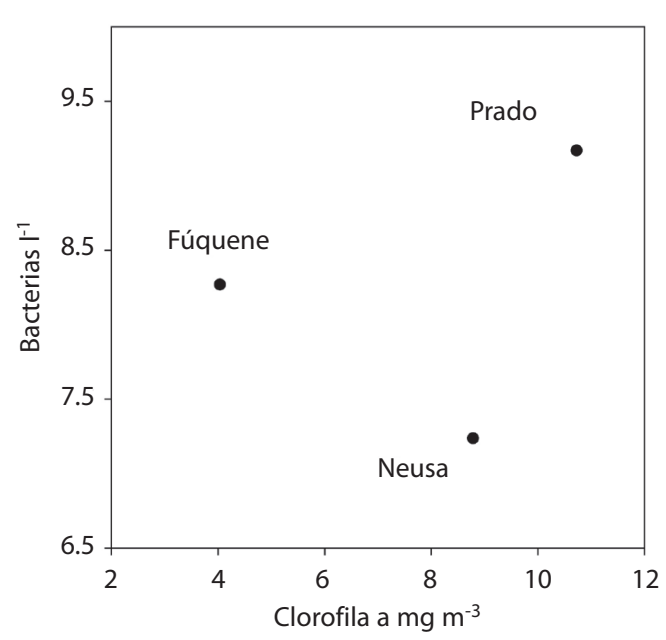

Fig. 5. Relación entre los promedios de abundancia bacteriana total y clorofila $a$ en los ecosistemas estudiados.

Fig. 5. Mean relationships between total bacterial abundance and chlorophyll $a$ in the ecosystems studied. 


\section{DISCUSIÓN}

Las variables fisicoquímicas mostraron que cada ecosistema es de características limnológicas distintas, lo que aparentemente influyó en la presencia y abundancia del fitoplancton pero no en la densidad del bacterioplancton. Los conteos totales de bacterias fueron similares en los tres ambientes con las dos técnicas empleadas (Prueba de Kruskall-Wallis= 2.1218, p=.3461, $\mathrm{n}=9$ ). Las densidades bacterianas encontradas en la columna de agua fueron similares a las de las regiones templadas. Benner et al. (1995), Pace and Cole (1996), Posch et al. (1997) y Tuomi et al. (1997) hallaron abundancias numéricas semejantes y poca variación cuando se estudian sistemas acuáticos muy diversos; algunos de estos trabajos sólo registran diferencias entre aguas oxigenadas y anóxicas. Según Cole et al. (1993) y Biddanda et al. (2001), la abundancia bacteriana en diferentes ecosistemas acuáticos varía solamente en uno a dos órdenes de magnitud $\left(10^{4}\right.$ a $10^{5}$ células $\left.\mathrm{ml}^{-1}\right)$, de manera similar a lo encontrado en este trabajo. No obstante, la actividad bacteriana tiende a aumentar con el incremento en el estado trófico (Biddanda et al. 2001, Porter et al. 2004). Las densidades más altas halladas en el embalse de Prado, de aguas mesotróficas, quizás estén relacionadas con la mayor temperatura de sus aguas. La imposibilidad de encontrar una relación clara entre la abundancia numérica de bacterias y el estado trófico de los cuerpos de agua estudiados, posiblemente refleje que los cambios en la cantidad y tipo de nutrientes afectan más la estructura de la comunidad bacteriana a través, por ejemplo, del aumento o la disminución de poblaciones específicas.

A diferencia del bacterioplancton, la abundancia del fitoplancton varió de acuerdo conl estado limnológico de cada sitio. El bajo número de especies y la alta densidad en el embalse de Prado, así como la presencia de taxones indicadores de eutrofia y materia orgánica como algunas cianobacterias (Anabaena raciborski), zigofíceas (Staurastrum af. natator) y clorofíceas (Crucigenia tetrapedia), están en concordancia con sus condiciones eutróficas.
En Fúquene la densidad de algas fue notoriamente menor debido a las condiciones de oligo a mesotrofia encontrados durante el desarrollo del estudio; las desmidias fueron variadas pero escasas por la alta mineralización de sus aguas, ya que las algas de este grupo prefieren ambientes de baja conductividad (Duque and Donato 1992). En Neusa prosperaron algunas especies de ambientes más transparentes y pobres en fósforo (cuadro 3), como por ejemplo las diatomeas, en especial una especie del género Synedra.

El dendograma de similitud del fitoplancton (Fig. 3) mostró que efectivamente cada ecosistema tiende a tener una composición de especies característica. Las condiciones oligo a mesotróficas más cercanas entre el embalse de Neusa y la laguna de Fúquene se reflejan en cierto grado de similitud que se presenta entre estos dos ambientes. De esta manera, la estación 1 de Fúquene (entrada del afluente) se asemeja en su composición y abundancia a las estaciones del Neusa.

La correlación entre las abundancias del fitoplancton y el bacterioplancton total (Pearson= -0.4479, $\mathrm{p}=0.019, \mathrm{n}=27$ ) indicó que las bacterias disminuyen cuando las algas aumentan, lo que podría mostrar algún fenómeno de competencia entre las dos comunidades, posiblemente por fósforo (Niño 2003). Biddanda et al. (2001) hallaron una mayor participación de bacterias en la biomasa planctónica total de aguas oligotróficas que eutróficas, lo que según los autores señalaría carencia de ensamblaje entre éstas y las algas. En este trabajo no se encontraron relaciones positivas entre las dos comunidades, a pesar de estudiar cuerpos de agua con variado estado trófico, por lo que puede decirse que los resultados evidenciaron un acoplamiento débil o inexistente entre bacterias y fitoplancton. Además, la correlación entre bacterias y $\mathrm{DBO}_{5}$, indica que la materia orgánica parece ser un sustrato importante para el bacterioplancton, lo que hace pensar que bacterias y fitoplancton responden independientemente a los nutrientes y elementos presentes en el agua. Una visión similar de reducido acoplamiento entre las dos 
comunidades se puede deducir de la Fig. 5, en la que no se ve un patrón claro de relación entre la concentración de pigmentos fotosintéticos de las algas y la abundancia de bacterias. La relación positiva entre el fitoplancton y las bacterias heterótrofas (Pearson $=0.3866, \mathrm{p}=0.062, \mathrm{n}=24$ ) fue débil (aceptable solo al 90\% de confianza) y puede deberse más a efectos azarosos.

Sería importante indagar cuáles son los mecanismos de control de ambas comunidades. Los resultados muestran que no solo la disponibilidad de sustrato favorece o limita su desarrollo, probablemente factores como la depredación por zooplancton y la lisis viral puedan explicar esta falta de acoplamiento. Un mayor número de muestreos en escala vertical y horizontal, así como en frecuencia temporal, que involucren un mayor grupo de microorganismos participantes en las cadenas tróficas acuáticas, permitirán visualizar mejor cómo se dan las interacciones entre el bacterioplancton y el fitoplancton en los ecosistemas tropicales estudiados.

\section{AGRADECIMIENTOS}

Este trabajo fue financiado por la Universidad Jorge Tadeo Lozano y por COLCIENCIAS mediante el contrato RC 124-96. Los autores agradecen a estas instituciones, en especial a Roberto Quiñones, ex-asesor del Programa de Medio Ambiente y Hábitat de COLCIENCIAS y a las personas del Laboratorio de Microbiología y del Centro de Investigaciones Científicas y Estudios Ambientales de la Universidad, que participaron directa e indirectamente en el trabajo, particularmente a los pasantes de microbiología Carolina García y Juan Pablo Niño.

\section{RESUMEN}

Analizamos las fracciones de fitoplancton y bacterioplancton en tres ecosistemas lénticos (los embalses de Neusa y Prado y la laguna de Fúquene), con características fisicoquímicas distintas, a fin de verificar el acoplamiento entre estas comunidades. Las muestras se tomaron en tres sitios de cada cuerpo de agua, en tres visitas de muestreo. El embalse de Neusa (meso a oligotrófico) mostró la menor concentración de bacterias; el embalse de Prado (eutrófico) tuvo una alta abundancia, tanto de algas como de bacterias. La laguna de Fúquene (oligo a mesotrófica) tuvo bajas concentraciones de fitoplancton, pero relativamente altas concentraciones de bacterias, debido a sus condiciones particulares de elevada concentración de materia orgánica y cantidades bajas de nutrientes en el agua. Se presentó una relación negativa entre el bacterioplancton total y el fitoplancton (Person $=-0.4479, \mathrm{p}=0.019, \mathrm{n}=27$ ) y positiva entre el fitoplancton y las bacterias heterótrofas (Pearson= $0.3866, \mathrm{p}=0.062, \mathrm{n}=24$ ) y entre las bacterias y la materia orgánica (Pearson $=0.4088, \mathrm{p}=0.034, \mathrm{n}=27$ ). El bacterioplancton total y el fitoplancton no mostraron "acoplamiento", pero las bacterias cultivables y el fitoplancton tuvieron algún grado de interrelación.

Palabras clave: Bacterioplancton, fitoplancton, región Andina, Colombia.

\section{REFERENCIAS}

American Public Health Association (APHA), American Water Works Association (AWWA) \& Water Pollution Control Federation (WPCF). 1995. Standard Methods for the Examination of Water and Wastewater. United Book. Baltimore, EEUU.

Benner, R., S. Opsahl, G. Chin-Leo, J. Richey \& B. Forsberg. 1995. Bacterial carbon metabolism in the Amazon river system. Limnol. Oceanogr. 40: 12621270.

Biddanda, B., M.Ogdahl \& J. Cotner. 2001. Dominance of bacterial metabolism in oligotrophic relative to eutrophic waters. Limnol. Oceanogr. 46: 730-739.

Blalock, H. 1979. Social Statistics. McGraw Hill, Nueva York, EEUU.

Canosa, A. \& G. Pinilla. 1999. Bacteriological eutrophication indicators in four colombian water bodies (South America). Lakes Reserv. Res. Manage. 4:23-27.

Canosa, A. \& G. Pinilla. 2001. Total bacterial populations in three lentic water bodies of the Colombian Andes using the epifluorescence technique. Lakes Reserv. Res. Manage. 6:169-174.

Canosa, A. 2003. Distribución de virus y bacteriófagos y su relación con las bacterias y los coliformes en tres cuerpos de agua lénticos de la región central de Colombia. Informe final Universidad Jorge Tadeo Lozano y Fundación para la Promoción de la Ciencia y de la Tecnología del Banco de la República. Bogotá, Colombia. 31p.

Cole, J., M. Pace, N. Caraco \& G. Steinhart. 1993. Bacterial biomass and cell size distributions in lakes: More and 
larger cells in anoxic waters. Limnol. Oceanogr. 38: 1627-1632.

Coveney, M. \& R. Wetzel. 1995. Biomass, production, and specific growth rate of bacterioplankton and coupling to phytoplankton in an oligotrophic lake. Limnol. Oceanogr. 40: 1187-1200.

Currie, D.J. 1990. Large-scale variability and interactions among phytoplankton, bacterioplankton, and phosphorous. Limnol. Oceanogr. 35: 1437-1455.

Del Giorgio, P.A., J.J. Cole \& A. Cimbleris. 1997. Respiration rates in bacteria exceed phytoplankton production in unproductive aquatic systems. Nature 385: 148-151.

Duque, S. 1996. Caracterización de ecosistemas acuáticos epicontinentales de Colombia con base en el fitoplancton. Institito de Hidrología, Meteorología y Estudios Ambientales (IDEAM), Bogotá, Colombia. $25 \mathrm{p}$.

Duque, S. \& J. Donato. 1992. Biología y ecología del fitoplancton de las aguas dulces en Colombia. Cuadernos Divulgativos Universidad Javeriana. Bogotá, Colombia. $21 \mathrm{p}$.

Goecke K., C. Hernández, H. Giesenhagen \& H. Hoppe 2004. Seasonal variations of bacterial abundance and biomass and their relation to phytoplankton in the hypertrophic tropical lagoon Ciénaga Grande de Santa Marta, Colombia. J. Plankton Res. 26:1429-1439.

Gómez, M. \& G. Pinilla. 1996. Efectos de la elodea (Egeria densa) en la laguna de Fúquene durante el primer semestre de 1993. p. 161-180 In G. Pinilla (ed.) Memorias del Seminario Taller "Investigaciones Limnológicas Recientes en Ecosistemas Acuáticos Tropicales". Universidad Jorge Tadeo Lozano. Bogotá, Colombia.

Hammer, O., D.A.T. Harper \& P.D. Ryan. 2001. PAST: Paleontological Statistics software for education and data analysis. Paleontol Electrónica 4:9

Havens, K.E., K.A. Work \& T.L. East. 2000. Relative efficiencies of carbon transfer from bacteria and algae to zooplankton in a subtropical lake. J Plankton Res. 22: 1801-1809.

Kepner, R. \& J. Pratt. 1994. Use of fluorochromes for direct enumeration of total bacteria in environmental samples: past and present. Microbiol. Rev. 58: 603-615.

Lund, J.W., C. Kipling \& E.D. Le Cren. 1958. The inverted microscope method of estimating algal number and the statistical basis of estimations by counting. Hydrobiologia 11: 143-170.
Márquez, G. \& G. Guillot. 1988. Proyecto estudios ecológicos de embalses colombianos. Etapa Prospectiva, Informe Final. Fondo FEN. Universidad Nacional de Colombia. Bogotá, Colombia. 242p.

Niño, J. P. 2003. Variación espacio-temporal del nitrógeno y el fósforo en el embalse del Neusa. Tesis Maestría Biología-Ecología. Universidad Nacional de Colombia, Bogotá, Colombia.. 70 p.

Pace, M. \& J. Cole. 1996. Regulation of bacteria by resources and predation tested in whole-laked experiments. Limnol. Oceanogr. 41: 1448-1460.

Pinilla, G. 1998. Indicadores biológicos en ecosistemas acuáticos continentales de Colombia. Compilación bibliográfica. Universidad Jorge Tadeo Lozano, Bogotá, Colombia. 67 p.

Pino, J.C. 1995. El fitoplancton y el estado trófico de los embalses de Chuza, Neusa y Tominé. Tesis, Universidad Jorge Tadeo Lozano, Bogotá, Colombia. 82 p.

Porter J, S. A. Morris \& R. W. Pickup. 2004. Effect of trophic status on the culturability and activity of bacteria from a range of lakes in the English Lake District. Appl. Environ. Microbiol. 70: 2072-2078.

Posch, T., J. Pernthaler, A. Alfreider \& R. Psenner. 1997. Cell-specific respiratory activity of aquatic bacteria studied with the tetrazolium reduction method, cyto-clear slides, and image analysis. Appl. Environ. Microbiol. 63: 867-873.

Ramírez, J. J. 2000. Fitoplancton de agua dulce: aspectos ecológicos, taxonómicos y sanitarios. Universidad de Antioquia, Medellín, Colombia. 207 p.

Roldán, G. 1992. Fundamentos de Limnología Neotropical. Universidad de Antioquia, Medellín, Colombia. 259 p.

Rosenstock, B. \& M. Simon. 2001. Sources and sinks of dissolved free amino acids and protein in a large and deep mesotrophic lake. Limnol. Oceanogr. 46: 644-654.

Tuomi, P., T. Torsvik, M. Heldal \& G. Bratbak. 1997. Bacterial population dynamics in a meromictic lake. Appl. Environ. Microbiol. 63: 2181-2188.

Vrede, F., T. Vrede, A. Isaksson \& A. Karlsson. 1999. Effects of nutrients (phosphorus, nitrogen, and carbon) and zooplankton on bacterioplankton and phytoplankton -a seasonal study. Limnol. Oceanogr. 44: 1616-1624.

Whitford, L. A. \& Schumacher, G. J. 1968. A manual of the freshwater algae in North Carolina. Raleigh, North Carolina, EEUU. 